\title{
FUNGSI UNDANG-UNDANG NOMOR 30 TAHUN 2014 TENTANG ADMINISTRASI PEMERINTAHAN TERHADAP KUALITAS PENYELENGGARAAN PEMERINTAHAN DI INDONESIA
}

\author{
${ }^{1}$ M. Yusuf Leman \\ ${ }^{1}$ Universitas Islam Syekh-Yusuf Tangerang \\ Email: myusufleman01@gmail.com
}

\begin{abstract}
ABSTRAK
Tulisan yang beriudul FUNGSI UNDANG-UNDANG NOMOR 30 TAHUN 2014 TENTANG ADMINISTRASI PEMERINTAHAN TERHADAP KUALITAS PENYELENGGARAAN PEMERINTAHAN DI INDONESIA ini, disamping memuat setidaknya 10 (sepuluh) pengertian yang berhubungan dengan pemerintahan, yaitu pengertian tentang; pemerintah, pemerintahan, kekuasaan pemerintahan, administrasi pemerintahan, fungsi pemerintahan, badan dan/atau pejabat pemerintahan, kewenangan pemerintahan, keputusan administrasi pemerintahan, tindakan administrasi pemerintahan, dan kualitas penyelenggaraan pemerintahan, tetapi juga membahas tentang; 1. Seberapa penting Undang-Undang Nomor 30 tentang Administrasi Pemerintahan di Indonesia; dan 2. Kualitas yang diinginkan didalam penyelenggaraan pemerintahan di Indonesia. Didalam pembahasan dua hal tersebut, didapat suatu kesimpulan yaitu: 1. Bahwa Undang-Undang Nomor 30 tentang Administrasi Pemerintahan, sangatlah penting dan diperlukan di Indonesia, yaitu untuk sebagai acuan dalam meningkatkan kualitas penyelenggaraan pemerintahan itu sendiri, dan 2. Bahwa kualitas yang diinginkan didalam penyelenggaraan pemerintahan di Indonesia adalah:

a. Bahwa Badan dan/atau Pejabat Pemerintahan dalam menggunakan wewenangnya haruslah mengacu pada Asas-asas Umum Pemerintahan yang Baik (AUPB), dan berdasarkan ketentuan Peraturan Perundang-undangan, seperti yang diatur pada Undang-Undang Nomor 30 Tahun 2014 tentang Administrasi Pemerintahan.

b. Tercapainya tujuan administrasi pemerintahan yang mengacu pada Pasal 3 UndangUndang Nomor 30 Tahun 2014 tentang Administrasi Pemerintahan.

c. Terwujudnya hak dan kewajiban pejabat pemerintahan yang mengacu pada Pasal 6 dan 7 Undang-Undang Nomor 30 Tahun 2014 tentang Administrasi Pemerintahan.

d. Terwujudnya kewenangan pemerintahan yang berdasarkan Peraturan Perundangundangan dan asas-asas umum pemerintahan yang baik (AUPB), yang mengacu pada Pasal 8 sampai 12 Undang-Undang Nomor 30 Tahun 2014 tentang Administrasi Pemerintahan.
\end{abstract}

Kata kunci: Fungsi, UU No. 30 Tahun 2014 tentang Administrasi Pemerintahan, Kualitas, Penyelenggaraan Pemerintahan di Indonesia. 


\section{A. PENDAHULUAN}

Setiap negara yang merdeka dan berdaulat, pastilah berkeinginan untuk menjadikan negaranya sebagai Negara yang berjaya, maju, dikenal, sejahtera, adil, dan berkepastian hukum. Begitu juga dengan halnya Negara Kesatuan Republik Indonesia yang saat ini telah berusia tidak muda lagi, karena sudah melampaui usia yang ke-72 tahun, sudah dapat dipastikan pula mempunyai keinginan dan harapan yang besar, yaitu agar supaya cita-cita atau tujuan luhur para pendiri negara ini akan segera semakin mendekati ketercapaiannya, walaupun dengan cara bertahap dari tahun sebelumnya, ketahun sekarang, dan dari tahun sekarang ke tahun berikutnya, dan seterusnya.

Adapun cita-cita atau tujuan yang luhur Negara Indonesia sebagaimana yang telah dipahami bersama yaitu setidaknya oleh 50\% rakyat Indonesia, dan yang termaktub pula dalam pembukaan (preambul) Undang-Undang Dasar Negara Kesatuan Republik Indonesia Tahun 1945, yang berbunyi yaitu: ...melindungi segenap bangsa Indonesia dan seluruh tumpah darah Indonesia dan untuk memajukan kesejahteraan umum, mencerdaskan kehidupan bangsa, dan ikut melaksanakan ketertiban dunia yang berdasarkan kemerdekaan, perdamaian abadi, dan keadilan sosial.

Sementara untuk mencapai keinginan dan harapan yang besar terhadap terwujudnya tujuan Negara Indonesia, sebagaimana yang dikemukakan dimuka, pemerintah Indonesia yang berdiri sejak diploklamirkannya kemerdekaan Indonesia 17 Agustus Tahun 1945, telah berupaya keras menggerakan roda pemerintahannya dengan melaksanakan pembangunan-pembangunan disegala sektor dan bidang yang dibutuhkan oleh Negara Indonesia untuk memenuhi kebutuhan hidup warga negaranya. Dan agar gerakan pembangunan yang dilakukan, yaitu mulai dari perencanaan, penetapan apa yang direncanakan, pelaksanaan, sampai dengan pengawasan, evaluasi dan selanjutnya dilakukan perencanaan kembali ditahun berikutnya mencapai keberhasilan yang signifikan, maka haruslah didukung oleh pemerintahan yang berkualitas. Didalam hal apa yang diuraikan diatas, dari pengamatan penulis, dapat disampaikan disini, bahwa pemerintah Indonesia telah melaksanakan upaya-upaya yang sangat positif dan serius untuk menunjukkan pemerintah yang berhasil dan berdaya guna didalam melaksanakan hak dan kewajibannya sebagaimana penyelenggara pemerintahan, dengan cara membuat payung hukum untuk dijadikan landasan berpijak dari setiap langkah mereka bekerja. Adapun payung hukum tersebut adalah Undang-Undang Nomor 30 Tahun 2014 tentang Administrasi Pemerintahan.

98 I Pelita - Jurnal Penelitian dan Karya Ilmiah 
FUNGSI UNDANG-UNDANG NOMOR 30 TAHUN 2014 TENTANG ADMINISTRASI PEMERINTAHAN TERHADAP KUALITAS PENYELENGGARAAN PEMERINTAHAN DI INDONESIA

\section{Yusuf Leman}

Atas dasar uraian diatas, serta diiringi dengan keinginan untuk mengetahui secara mendalam dan sekaligus membantu mensosialisasikan Undang-Undang tentang Administrasi Pemerintahan sebagaimana yang dimaksud dimuka, maka penulis mengangkat masalah ini dalam bentuk tulisan yang berjudul FUNGSI UNDANG-UNDANG NOMOR 30 TAHUN 2014 TENTANG ADMINISTRASI PEMERINTAHAN TERHADAP KUALITAS PENYELENGGARAAN PEMERINTAHAN DI INDONESIA.

\section{Perumusan Masalah}

Pada perumusan masalah dalam tulisan ini, penulis mengangkat rumusan sebagai berikut: 1. Seberapa penting Undang-Undang Nomor 30 tentang Administrasi Pemerintahan didalam penyelenggaraan pemerintahan di Indonesia; 2. Kualitas yang bagaimana yang diinginkan atau diharapkan dalam penyelenggaraan pemerintahan di Indonesia.

\section{Tujuan Penulisan}

Adapun tujuan yang terkandung didalam penulisan UndangUndang Nomor 30 tentang Administrasi Pemerintahan di Indonesia ini adalah, disamping untuk mengetahui secara mendalam dan membantu mensosialisasikan tentang undang-undang ini, tetapi juga sekaligus untuk mengetahui pula bagaimana dampak yang ditimbulkan didalam menggunakan undang-undang ini sebagai landasan atau panduan dalam penyelenggaraan pemerintahan di Indonesia sekarang ini.

\section{Manfaat Penulisan}

Mengenai manfaat yang dapat diharapkan dalam tulisan ini adalah antara lain; 1. Manfaat untuk penulis sendiri adalah sudah jelas atau dipastikan akan menambah wawasan dan meningkatkan kemampuan pemahaman dalam penulisan, serta akan terus memotivasi untuk menulis; 2. Manfaaat untuk institusi/lembaga Universitas Islam Syekh Yusuf (UNIS) Tangerang, dan/atau Fakultas Ilmu Sosial dan Ilmu Politik (FISIP) UNIS Tangerang, adalah bahwa tulisan ini dapat dijadikan sebagai literatur kepustakaan; dan 3. Manfaat untuk mahasiswa dan peminat pembaca lainnya, Insya Allah tulisan ini dapat dijadikan sebagai bahan tambahan bacaan yang berguna dan bersifat akademik. 


\section{B. TINJAUAN PUSTAKA Pengertian Pemerintah}

Menurut Kamus Besar Bahasa Indonesia Departemen Pendidikan dan Kebudayaan terbitan Balai Pustaka (1998:672), pemerintah ialah; 1. Menjalankan wewenang dan kekuasaan mengatur kehidupan sosial, ekonomi, dan politik suatu Negara atau bagian-bagiannya; 2. Sekelompok orang yang secara bersama-sama memikul tanggung jawab terbatas untuk menggunakan kekuasaan; 3. Penguasaan suatu negara (bagian negara); 4. Badan tertinggi yang memerintah suatu negara (seperti kabinet) merupakan suatu pemerintah; 5. Negara atau negeri (sebagai lawan partikelir atau swasta); 6. Pengurus (pengelola).

Adapun pengertian pemerintahan berdasarkan Kamus Besar Bahasa Indonesia Departemen Pendidikan dan Kebudayaan terbitan Balai Pustaka (1998:673), pemerintahan adalah; 1. Proses, cara, perbuatan memerintah; 2. Segala urusan yang dilakukan oleh negara dalam menyelenggarakan kesejahteraan masyarakat dan kepentingan negara.

\section{Pengertian Kekuasaan Pemerintahan}

Didalam hal kekuasaan pemerintahan, sebagaimana dijelaskan dalam Undang-Undang Dasar Negara Republik Indonesia Tahun 1945, Pasal 4 ayat (1) (2014:9), bahwa Presiden Republik Indonesia memegang kekuasaan pemerintahan menurut Undang-Undang Dasar. Dan diayat (2) nya (2014:9), disebutkan bahwa dalam melakukan kewajibannya Presiden dibantu oleh satu orang Wakil Presiden.

Lebih jauh menurut Sumpena (2011:51), mengatakan : berbicara pemerintahan, berarti tidak terlepas dari berbicara tentang badan-badan negara, baik Eksekutif (Pemerintah), Legislatif (DPR), ataupun Yudikatif (Kehakiman) yang dalam hal ini juga berkaitan dengan pemerintahan didaerah (Provinsi dan Kabupaten/Kota).

\section{Pengertian Kewenanangan Pemerintahan}

Menurut Undang-Undang Republik Indonesia Nomor 30 Tahun 2014 tentang Administrasi Pemerintahan (2014:3), bahwa kewenangan pemerintahan adalah kekuasaan Badan dan/atau Pejabat Pemerintahan atau penyelenggara lainnya untuk bertindak dalam ranah hukum publik.

\section{Pengertian Keputusan Administrasi Pemerintahan}

Keputusan administrasi pemerintahan yang juga disebut keputusan tata usaha negara atau keputusan administrasi negara menurut UndangUndang Nomor 30 Tahun 2014 tentang Administrasi Pemerintahan (2014:3) 
FUNGSI UNDANG-UNDANG NOMOR 30 TAHUN 2014 TENTANG ADMINISTRASI PEMERINTAHAN TERHADAP KUALITAS PENYELENGGARAAN PEMERINTAHAN DI INDONESIA

M. Yusuf Leman

adalah ketetapan tertulis yang dikeluarkan oleh Badan dan/atau Pejabat Pemerintahan dalam penyelenggaraan pemerintahan.

\section{Pengertian Tindakan Administrasi Pemerintahan}

Yang dimaksud dengan tindakan administrasi pemerintahan menurut Undang-Undang Nomor 30 Tahun 2014 tentang Administrasi Pemerintahan (2014:3) adalah perbuatan pejabat pemerintahan atau penyelenggara negara lainnya untuk melakukan dan/atau tidak melakukan perbuatan konkreat dalam rangka penyelenggaraan pemerintahan.

\section{Pengertian Kualitas}

Didalam Kamus Besar Bahasa Indonesia Departemen Pendidikan dan Kebudayaan terbitan Balai Pustaka (1988:467) disebutkan, bahwa kualitas adalah; 1. Tingkat baik buruknya sesuatu, kadar; 2. Derajat atau taraf (kepandaian, kecakapan, dan sebagainya), mutu.

\section{Pengertian Penyelenggaraan}

Yang dimaksud dengan penyelenggaraan berdasarkan Kamus Besar Bahasa Indonesia Departemen Pendidikan dan Kebudayaan terbitan Balai Pustaka (1988:801) adalah; 1. Pemeliharaan, pemiaraan; proses, perbuatan, cara menyelenggarakan diberbagai-bagai arti. (seperti; pelaksanaan, penunaian, dan sebagainya).

\section{Pengertian Kualitas Penyelenggaraan Pemerintahan}

Untuk mengetahui apa yang dimaksud dengan kualitas penyelenggaraan pemerintahan, penulis akan menggabungkan ketiga pengertian kata-kata diatas, yaitu kualitas, penyelenggaraan, dan pemerintahan, menjadi satu pengertian dari sebuah istilah yaitu kualitas penyelenggaraan pemerintah. Kalau pengertian pemerintahan sebagaimana disebutkan pada B.2 diatas adalah; 1 . Proses, cara, perbuatan memerintah; 2. Segala urusan yang dilakukan oleh negara dalam menyelenggarakan kesejahteraan masyarakat dan kepentingan negara, sementara pengertian kualitas sebagaimana disebutkan pada B.10 diatas adalah; 1. Tingkat baik buruknya sesuatu, kadar; 2. Derajat atau taraf (kepandaian, kecakapan, dan sebagainya), mutu, sedangkan pengertian penyelenggaraan sebagaimana disebutkan pada B.11 diatas adalah; 1. Pemeliharaan, pemiaraan; proses, perbuatan, cara menyelenggarakan diberbagai-bagai arti. (seperti; pelaksanaan, penunaian, dan sebagainya). 
Maka pengertian kualitas penyelenggaraan pemerintahan dapat diartikan (mengandung arti) "nilai yang dihasilkan dalam menyelenggarakan suatu urusan yang dilakukan oleh negara dalam pencapaian kesejahteraan masyarakat dan kepentingan negara".

Sehubungan dengan pengertian diatas, dan dihubungkan dengan judul tulisan ini, maka pembahasan nanti, penulis akan mengambil suatu penilaian tentang penyelenggaraan pemerintahan di Indonesia, apakah kualitasnya akan termasuk kedalam kualitas yang didambahkan oleh masyarakat atau tidak. Kalau didambahkan, berarti kualitasnya dinilai baik dan dikatakan sebagai penopang dari tujuan negara kita yang berbunyi sebagaimana yang disebutkan dalam pembukaan (preambul) UndangUndang Dasar 1945, dan telah dikutip serta dicantumkan dimuka oleh penulis dalam tulisan ini.

\section{PEMBAHASAN UMUM}

Diawal tulisan ini, yaitu pada latar belakang telah disebutkan bahwa untuk mencapai keinginan dan harapan yang besar terhadap terwujudnya tujuan Nasional Negara Indonesia, yang berbunyi sebagaimana yang ada di preambul (pembukaan) Undang-Undang Dasar 1945, dan oleh penulis tujuan tersebut dikutip dan dicantumkan pula pada awal tulisan ini, haruslah didukung oleh pemerintahan yang berkualitas. Dan untuk menjadikan pemerintahan yang berkualitas tersebut, perlu pula didukung oleh instrumen pendukung yang dapat dijadikan landasan berpijak dalam setiap langkah penyelenggaraan negara, seperti mengambil kebijakan-kebijakan atau keputusan-keputusan untuk memenuhi kebutuhan hukum masyarakat sehingga tercipta keadilan dan kepastian hukum.

Didalam hal untuk merealisasikan apa yang diuraikan diatas, pemerintah Indonesia telah membuat instrumen dalam bentuk seperangkat peraturan yang dituangkan dalam undang-undang. Adapun undangundang tersebut adalah Undang-Undang Republik Indonesia Nomor 30 Tahun 2014 tentang Administrasi Pemerintahan. Dan undang-undang inilah yang sekarang dijadikan sebagai payung hukum bagi penyelenggara pemerintahan di Indonesia. Dan disamping sebagai payung hukum bagi penyelenggara pemerintahan, dikatakan oleh penerbit Sinar Grafika (2014:5), bahwa Undang-Undang Republik Indonesia Nomor 30 Tahun 2014 tentang Administrasi Pemerintahan ini dimaksudkan tidak hanya sebagai payung hukum bagi penyelenggara pemerintahan, tetapi juga sebagai instrumen untuk meningkatkan kualitas pelayanan pemerintahan 
FUNGSI UNDANG-UNDANG NOMOR 30 TAHUN 2014 TENTANG ADMINISTRASI PEMERINTAHAN TERHADAP KUALITAS PENYELENGGARAAN PEMERINTAHAN DI INDONESIA

M. Yusuf Leman

kepada masyarakat sehingga keberadaan undang-undang ini benar-benar dapat mewujudkan pemerintahan yang baik bagi semua Badan dan/atau Pejabat Pemerintahan dipusat dan didaerah. Lebih lanjut disebutkan juga bahwa Undang-Undang Nomor 30 Tahun 2014 tentang Administrasi Pemerintahan ini merupakan keseluruhan upaya untuk mengatur kembali keputusan dan/atau tindakan badan berdasarkan ketentuan Peraturan Perundang-undangan dan AUPB (Asas-Asas Umum Pemerintahan yang Baik).

Seberapa Penting Undang-Undang Nomor 30 Tahun 2014 Tentang Administrasi Pemerintahan Di Indonesia

Untuk mengetahui didalam hal seberapa penting Undang-Undang Nomor 30 Tahun 2014 tentang Administrasi Pemerintahan ini diperlukan didalam penyelenggaraan pemerintahan di Indonesia, marilah kita bahas melalui uraian dan bahasan sebagai berikut :

\section{Tentang Fungsi Pemerintahan}

Sebagaimana diuraikan dimuka, bahwa fungsi pemerintahan adalah fungsi dalam melaksanakan administrasi pemerintahan yang meliputi fungsi pengaturan, pelayanan, pembangunan, pemberdayaan, dan perlindungan. Didalam hal untuk mewujudkan dan melaksanakan baik fungsi pengaturan, fungsi pelayanan, fungsi pembangunan, dan fungsi pemberdayaan, serta fungsi perlindungan ini, sudah barang tentu pemerintah tidak bisa melaksanakan dengan sesuka hati sesuai dengan selera mereka yang sedang berkuasa, tetapi haruslah benarbenar dilaksanakan dengan dasar dan niat untuk menghasilkan pengaturan yang sempurna, dan tepat, yaitu pelayanan yang baik, pembangunan yang berhasil dan berdaya guna, pemberdayaan yang merata, perlindungan yang adil dan sesuai dengan Hak Asasi Manusia (HAM). Dan untuk mewujudkan ini semua, pemerintah telah membuat landasan hukum yang disesuaikan dengan kebutuhan hukum masyarakat dalam penyelenggaraan pemerintahan, yaitu Undang-Undang Nomor 30 Tahun 2014 tentang Administrasi Pemerintahan. 


\section{Tentang Badan Dan/Atau Pejabat Pemerintah}

Sebagaimana yang diuraikan dimuka, bahwa Badan dan/atau Pejabat Pemerintah adalah unsur yang melaksanakan fungsi pemerintahan, baik dilingkungan pemerintah maupun penyelenggara Negara lainnya. Didalam hal melaksanakan fungsi pemerintahan, baik dilingkungan pemerintah maupun penyelenggara negara lainnya, haruslah pula tetap mengacu pada pedoman dan aturan-aturan yang berpihak kepada rakyat. Dan aturan-aturan tersebut telah disiapkan oleh Pemerintah dan Dewan Perwakilan Rakyat, yaitu UndangUndang Nomor 30 Tahun 2014 tentang Administrasi Pemerintahan.

\section{Tentang Kewenangan Pemerintahan}

Sebagaimana diuraikan dimuka, bahwa kewenangan pemerintahan adalah kekuasaan Badan dan/atau Pejabat Pemerintah atau Penyelenggara negara lainnya untuk bertindak dalam ranah hukum publik. Didalam hal untuk melaksanakan kekuasaan oleh Badan dan/atau Pejabat Pemerintahan atau Penyelenggara negara lainnya untuk bertindak dalam ranah hukum publik, berarti bertindak berdasarkan aturan-aturan yang sudah disepakati. Dan didalam hal ini adalah Undang-Undang Nomor 30 Tahun 2014 tentang Administrasi Pemerintahan.

\section{Tentang Keputusan Administrasi Pemerintah}

Sebagaimana dikemukakan dimuka, bahwa keputusan administrasi pemerintah yang juga disebut keputusan tata usaha negara atau keputusan administrasi negara adalah ketetapan tertulis yang dikeluarkan oleh Badan dan/atau Pejabat Pemerintahan dalam penyelenggaraan pemerintahan. Didalam hal mengeluarkan setiap ketetapan tertulis yang dikeluarkan oleh Badan dan/atau Pejabat Pemerintahan dalam penyelenggaraan pemerintahan, haruslah pula berdasarkan pada aturan-aturan yang berlaku dan telah disepakati. Dan dalam hal ini, aturan yang menjadi acuan adalah Undang-Undang Nomor 30 Tahun 2014 tentang Administrasi Pemerintahan. 
FUNGSI UNDANG-UNDANG NOMOR 30 TAHUN 2014 TENTANG ADMINISTRASI PEMERINTAHAN TERHADAP KUALITAS PENYELENGGARAAN PEMERINTAHAN DI INDONESIA

M. Yusuf Leman

\section{Tentang Tindakan Administrasi Pemerintahan}

Sebagaimana diuraikan dimuka, bahwa tindakan administrasi pemerintahan adalah perbuatan pejabat pemerintahan atau penyelenggara negara lainnya untuk melakukan dan/atau tidak melakukan perbuatan konkreat dalam rangka penyelenggaraan pemerintahan. Didalam hal untuk melakukan dan/atau tidak melakukan perbuatan konkreat dalam rangka penyelenggaraan pemerintahan oleh pejabat pemerintahan atau oleh penyelenggara negara lainnya, haruslah pula tetap berpedoman atau berdasarkan pada aturan-aturan yang berlaku dan disepakati. Dan untuk sekarang ini aturan-aturan yang berlaku dan disepakati dimaksud adalah Undang-Undang Nomor 30 Tahun 2014 tentang Administrasi Pemerintahan.

Dari semua uraian dan pembahasan diatas, yaitu mulai dari ; tentang fungsi pemerintahan, tentang Badan dan/atau Pejabat Pemerintahan, tentang kewenangan pemerintahan, tentang keputusan administrasi pemerintahan, dan tentang tindakan administrasi pemerintahan, serta kalaulah pula kita melihat maksud dan tujuan Undang-Undang Nomor 30 Tahun 2014 tentang Administrasi Pemerintahan, sebagaimana dinyatakan dalam Pasal 2 dan 3 didalam undang-undang tersebut (2014:5-6), bahwa Undang-Undang tentang Administrasi dimaksudkan sebagai salah satu dasar hukum bagi Badan dan/atau Pejabat Pemerintahan, warga masyarakat, dan pihak-pihak lain yang terkait dengan administrasi pemerintahan dalam upaya meningkatkan kualitas penyelenggaraan pemerintahan. Dan sedangkan tujuannya adalah ; a. menciptakan tertib penyelenggaraan administrasi pemerintahan; b. menciptakan kepastian hukum; c. mencegah terjadinya penyalahgunaan wewenang; d. menjamin akuntabilitas badan dan/atau pejabat pemerintahan; e. memberikan perlindungan hukum kepada warga masyarakat dan aparatur pemerintahan; f. melaksanakan ketentuan peraturan perundang-undangan dan menerapkan AUPB; dan g. memberikan pelayanan yang sebaik-baiknya kepada warga masyarakat; maka jelas dapat dikatakan bahwa Undang-Undang Nomor 30 Tahun 2014 tentang Administrasi Pemerintahan ini sangatlah penting, dan sangatlah diperlukan didalam penyelenggaraan pemerintahan di Indonesia, yaitu sebagai acuan untuk meningkatkan kualitas penyelenggaraan pemerintahan itu sendiri. 


\section{Kualitas Yang Di Inginkan Didalam Penyelenggaraan Pemerintahan Di Indonesia}

Untuk mengetahui tentang kualitas yang di inginkan atau diharapkan dalam penyelenggaraan pemerintahan di Indonesia, dapat kita ketahui dengan melihat dan membahasnya dari isi atau yang diisyaratkan oleh undang-undang tentang administrasi pemerintahan yang berlaku saat ini. Adapun undang-undang tentang administrasi pemerintahan yang terbaru dan berlaku saat ini adalah Undang-Undang Nomor 30 Tahun 2014 tentang Administrasi Pemerintahan, yang dibuat dengan persetujuan bersama antara Dewan Perwakilan Rakyat Republik Indonesia dengan Presiden Republik Indonesia, dan disahkan di Jakarta pada tanggal 17 Oktober 2014 oleh Presiden Republik Indonesia (Dr. H. Susilo Bambang Yudhoyono) serta diundangkan di Jakarta pada tanggal 17 Oktober 2014 oleh Menteri Hukum dan Hak Asasi Manusia (Amir Syamsudin), dan kemudian dicatatkan / ditempatkan dalam Lembaran Negara Republik Indonesia Tahun 2014 Nomor 292. Undang-undang ini terdiri dari XIV Bab, dan 89 Pasal, serta lengkap dengan penjelasannya.

Dan dengan penulis membaca secara seksama dari keseluruhan isi dari undang-undang yang dimaksud diatas, sangatlah banyak kriteriakriteria tentang kualitas yang diinginkan dalam penyelenggaraan pemerintahan di Indonesia. Namun demikian, dibawah ini penulis hanya mengetengahkan 4 (empat) kriteria saja. Adapun ke 4 (empat) kriteria kualitas yang diinginkan dalam penyelenggaraan pemerintahan di Indonesia adalah sebagai berikut:

\section{Menggunakan Kewenangan Dengan Mengacu Pada Aupb Dan Ketentuan Peraturan Perundang-Undangan Bagi Badan Dan/Atau Pejabat Pemerintahan}

Didalam penyelenggaraan pemerintahan di Indonesia, yaitu mulai dari pemerintahan dipusat sampai dengan pemerintahan di provinsi yang saat ini provinsi di Indonesia menurut Azmi Al Bahij (2013:3) adalah berjumlah 34 provinsi, haruslah diselenggarakan dengan sebaik-baiknya. Dan didalam klausal menimbang di alinea (a) pada Undang-Undang Nomor 30 Tahun 2014 tentang Administrasi Pemerintahan (2014:1) disebutkan; bahwa dalam rangka meningkatkan kualitas penyelenggaraan pemerintahan Badan dan/atau Pejabat Pemerintahan dalam menggunakan wewenang harus mengacu pada asas-asas umum pemerintahan yang baik dan berdasarkan ketentuan peraturan perundang-undangan. Adapun asasasas umum pemerintahan yang baik menurut Pasal 10 Undang-Undang Nomor 30 Tahun 2014 tentang Administrasi Pemerintahan ini (2014:11), adalah meliputi asas; a, kepastian hukum; b. kemanfaatan; c. ketidak 
FUNGSI UNDANG-UNDANG NOMOR 30 TAHUN 2014 TENTANG ADMINISTRASI PEMERINTAHAN TERHADAP KUALITAS PENYELENGGARAAN PEMERINTAHAN DI INDONESIA

M. Yusuf Leman

berpihakan; d. kecermatan; e. tidak menyalahgunakan kewenangan; $\mathbf{f}$. keterbukaan; g. kepentingan umum; dan $\mathbf{h}$. pelayanan publik.

\section{Tercapainya Tujuan Administrasi Pemerintahan}

Adapun kualitas penyelenggaraan pemerintahan di Indonesia lainnya yang diinginkan adalah tercapainya tujuan administrasi pemerintahan. Tujuan administrasi pemerintahan sebagaimana dicantumkan dalam Undang-Undang Nomor 30 Tahun 2014 tentang Administrasi Pemerintahan, yaitu (2014:6); a. menciptakan tertib penyelenggaraan administrasi pemerintahan; b. menciptakan kepastian hukum; c. mencegah terjadinya penyalahgunaan wewenang; d. menjamin akuntabilitas Badan dan/atau Pejabat Pemerintahan; e. memberikan perlindungan hukum kepada warga masyarakat dan aparatur pemerintahan; f. melaksanakan ketentuan peraturan perundangundangan, menerapkan AUPB; dan g. memberikan pelayanan yang sebaikbaiknya kepada warga masyarakat.

\section{Terwujudnya Hak Dan Kewajiban Pejabat Pemerintahan}

Disamping dua hal kualitas penyelenggaraan pemerintahan yang diinginkan diatas, terwujudnya hak dan kewajiban pemerintahan, juga merupakan kualitas yang diinginkan didalam penyelenggaraan pemerintahan di Indonesia. Sebagaimana yang disebutkan di Pasal 6 alinea (1) Undang-Undang Nomor 30 Tahun 2014 tentang Administrasi Pemerintahan (2014:7), bahwa pejabat pemerintahan memiliki hak untuk menggunakan kewenangan dalam mengambil keputusan dan/atau tindakan. Di alinea (2) nya disebutkan (2014:7-8), bahwa hak sebagaimana dimaksud pada ayat (1) meliputi : a. melaksanakan kewenangan yang dimiliki berdasarkan ketentuan peraturan perundang-undangan dan AUPB; b. menyelenggarakan aktivitas pemerintahan berdasarkan kewenangan yang dimiliki; c. menetapkan keputusan berbentuk tertulis atau elektronis dan/atau menetapkan tindakan; d. menerbitkan atau tidak menerbitkan, mengubah, mengganti, mencabut, menunda, dan/atau membatalkan keputusan dan/atau tindakan; e. menggunakan diskresi sesuai dengan tujuannya; f. mendelegasikan dan memberikan mandat kepada pejabat pemerintahan lainnya sesuai dengan ketentuan peraturan perundang-undangan; g. menunjuk pelaksana harian atau pelaksana tugas untuk melaksanakan tugas apabila pejabat definitif berhalangan; $\mathbf{h}$. menerbitkan izin, dispensasi, dan/atau konsesi sesuai dengan ketentuan peraturan perundang-undangan; i. memperoleh perlindungan hukum dan 
jaminan kemauan dalam menjalankan tugasnya; j. memperoleh bantuan hukum dalam pelaksanaan tugasnya; k. menyelesaikan sengketa kewenangan dilingkungan atau wilayah kewenangannya; 1. menyelesaikan upaya administratif yang diajukan masyarakat atas keputusan dan/atau tindakan yang dibuatnya; dan $\mathbf{m}$. menjatuhkan sanksi administratif kepada bawahan yang melakukan pelanggaran sebagaimana diatur dalam Undang-Undang Nomor 30 Tahun 2014 tentang Administrasi Pemerintahan.

Sementara di Pasal 7, alinea ke (1) disebutkan (2014:8), bahwa pejabat pemerintahan berkewajiban untuk menyelenggarakan administrasi pemerintahan sesuai dengan ketentuan peraturan perundang-undangan, kebijakan pemerintahan dan AUPB. Di alinea ke (2) disebutkan (2014:9), bahwa pejabat pemerintahan memiliki kewajiban : a. membuat keputusan dan/atau tindakan sesuai dengan kewenangannya; b. mematuhi AUPB dan sesuai dengan ketentuan peraturan perundang-undangan; c. mematuhi persyaratan dan prosedur pembuatan keputusan dan/atau tindakan; d. mematuhi undang-undang ini dalam menggunakan diskresi; e. memberikan bantuan kedinasan kepada Badan dan/atau Pejabat Pemerintahan yang meminta bantuan untuk melaksanakan penyelenggaraan pemerintahan tertentu; f. memberikan kesempatan kepada warga masyarakat untuk didengar pendapatnya sebelum membuat keputusan dan/atau tindakan sesuai dengan ketentuan peraturan perundang-undangan; g. memberitahukan kepada warga masyarakat yang berkaitan dengan keputusan dan/atau tindakan yang menimbulkan kerugian paling lama 10 hari kerja terhitung sejak keputusan dan/atau tindakan ditetapkan dan/atau dilakukan; $\mathbf{h}$. menyusun standar operasioanl prosedur pembuat keputusan dan/atau tindakan; i. memeriksa dan meneliti dokumen administrasi pemerintahan serta membuka askes dokumen administrasi pemerintahan kepada warga masyarakat kecuali ditentukan lain oleh undang-undang; j. menerbitkan keputusan terhadap permohonan warga masyarakat sesuai dengan hal-hal yang diputuskan dalam keberatan/banding; k. melaksanakan keputusan dan/atau tindakan yang sah dan keputusan yang telah dinyatakan tidak sah atau dibatalkan oleh pengadilan, pejabat yang bersangkutan, atau atasan pejabat; dan 1 . mematuhi putusan pengadilan yang telah berkekuatan hukum tetap. 
FUNGSI UNDANG-UNDANG NOMOR 30 TAHUN 2014 TENTANG ADMINISTRASI PEMERINTAHAN TERHADAP KUALITAS PENYELENGGARAAN PEMERINTAHAN DI INDONESIA

M. Yusuf Leman

\section{Terwujudnya Kewenangan Pemerintahan Yang Berdasarkan Peraturan Perundang-Undangan, Dan Aupb}

Sebagaimana dikemukakan dimuka, yaitu pada tinjauan pustaka, diktum B.7 disebutkan bahwa kewenangan pemerintahan adalah kekuasaan Badan dan/atau Pejabat Pemerintahan atau Penyelenggara Negara lainnya untuk bertindak dalam ranah hukum publik. Dan didalam menjalankan kewenangannya Badan dan/atau Pejabat Pemerintahan atau Pejabat Penyelenggaraan lainnya tidak dibenarkan dengan cara yang semena-mena atau serampangan, tetapi justru haruslah tetap berlandaskan kepada peraturan perundang-undangan dan AUPB.

Pada pasal 8, didalam Undang-Undang Nomor 30 Tahun 2014 tentang Administrasi Pemerintahan, disebutkan (2014:10), bahwa : 1. Setiap keputusan dan/atau tindakan harus ditetapkan dan/atau dilakukan oleh badan dan/atau pejabat pemerintahan yang berwenang; 2. Badan dan/atau Pejabat Pemerintahan dalam menggunakan wewenang wajib berdasarkan : a. peraturan perundang-undangan dan b. AUPB. 3. Pejabat administrasi pemerintahan dilarang menyalahgunakan kewenangan dalam menetapkan dan/atau melakukan keputusan dan/atau tindakan.

Selanjutnya pada Pasal 9 disebutkan (2014:10-11) bahwa: 1. Setiap keputusan dan/atau tindakan wajib berdasarkan ketentuan peraturan perundang-undangan dan AUPB; 2. Peraturan perundang-undangan sebagaimana dimaksud pada ayat (1) meliputi: a. peraturan perundangundangan yang menjadi dasar kewenangan; dan $\mathbf{b}$. peraturan perundangundangan yang menjadi dasar dalam menetapkan dan/atau melakukan keputusan dan/atau tindakan. 3. Badan dan/atau Pejabat Pemerintahan dalam menetapkan dan/atau melakukan keputusan dan/atau tindakan wajib mencantumkan atau menunjukan ketetentuan peraturan perundangundangan yang menjadi dasar kewenangan dan dasar dalam menetapkan dan/atau melakukan keputusan dan/atau tindakan. 4. Ketiadaan atau ketidak jelasan peraturan perundang-undangan sebagaimana dimaksud pada ayat (2) huruf (b) tidak menghalangi Badan dan/atau Pejabat Pemerintahan yang berwenang untuk menetapkan dan/atau melakukan keputusan dan/atau tindakan sepanjang memberikan kemanfaatan umum dan sesuai dengan AUPB.

Kemudian pada Pasal 10, (2014:11) disebutkan : 1. AUPB yang dimaksud dalam undang-undang ini meliputi asas : a. kepastian hukum; $b$. kemanfaatan; c. ketidak berpihakan; d. kecermatan; e. tidak menyalahgunakan kewenangan; f. keterbukaan; g. kepentingan umum; dan h. pelayanan yang baik. 2. Asas-asas umum lainnya diluar AUPB 
sebagaimana dimaksud pada ayat (1) dapat diterapkan sepanjang dijadikan dasar penilaian hakim yang tertuang dalam putusan pengadilan yang berkekuatan hukum tetap.

Didalam kewenangan yang diperoleh melalui atribusi; delegasi; dan/atau mandat, pada Pasal 12 Undang-Undang Nomor 30 Tahun 2014 tentang Administrasi Pemerintahan ini menyebutkan (2014:12), bahwa : 1 . Badan dan/atau Pejabat Pemerintahan memperoleh wewenang melalui atribusi apabila ; a. diatur dalam Undang-Undang Dasar Negara Republik Indonesia Tahun 1945 dan/atau Undang-Undang; b. merupakan wewenang baru atau sebelumnya tidak ada dan c. atribusi diberikan kepada badan dan/atau pejabat pemerintahan. 2. Badan dan/atau Pejabat Pemerintahan yang memperoleh wewenang melalui atribusi, tanggung jawab kewenangan berada pada Badan dan/atau Pejabat Pemerintahan yang bersangkutan. 3. Kewenangan atribusi tidak dapat didelegasikan, kecuali diatur didalam Undang-Undang Dasar Negara Republik Indonesia Tahun 1945 dan/atau Undang-Undang.

Dan pada Pasal 13, (2014:12-13) disebutkan bahwa: 1. Pendelegasian kewenangan ditetapkan berdasarkan ketentuan peraturan perundangundangan. 2. Badan / Pejabat Pemerintahan memperoleh wewenang melalui delegasi apabila : a. diberikan oleh Badan dan/atau Pejabat Pemerintahan kepada Badan dan/atau Pejabat Pemerintahan lainnya; b. ditetapkan dalam Peraturan Pemerintah, Peraturan Presiden, dan/atau Peraturan-peraturan Daerah; dan c. merupakan wewenang selanjutnya atau sebelumnya telah ada. 3. Kewenangan yang didelegasikan kepada Badan dan/atau Pejabat Pemerintahan tidak dapat didelegasikan lebih lanjut, kecuali ditentukan lain dalam peraturan perundang-undangan. 4. Dalam hal ketentuan peraturan perundang-undangan menentukan lain sebagaimana dimaksud pada ayat (3), badan dan/atau pejabat pemerintahan yang memperoleh wewenang melalui delegasi sebagaimana dimaksud pada ayat (2) dapat mensubdelegasikan tindakan kepada badan dan/atau pejabat pemerintahan lain dengan ketentuan : a. dituangkan dalam bentuk peraturan sebelum wewenang dilaksanakan; b. dilakukan dalam lingkungan pemerintahan itu sendiri; dan c. paling banyak diberikan kepada badan dan/atau pejabat pemerintahan 1 tingkat dibawahnya. 5 . Badan dan/atau Pejabat Pemerintahan yang memberikan delegasi dapat menggunakan sendiri wewenang yang telah diberikan melalui delegasi kecuali ditentukan lain dalam ketentuan peraturan perundang-undangan. 6. Dalam hal pelaksanaan wewenang berdasarkan delegasi menimbulkan ketidak efektifan penyelenggaraan pemerintahan, Badan dan/atau Pejabat Pemerintahan yang memberikan pendelehasian kewenangan dapat 
menarik kembali wewenangan yang telah didelagasikan. 7. Badan dan/atau Pejabat Pemerintah yang memperoleh wewenang melalui delegasi, tanggung jawab kewenangan berada pada penerima delegasi.

Selanjutnya pada Pasal 14 (2014:13) disebutkan, 1. Badan dan/atau Pejabat Pemerintah memperoleh mandat apabila: a. ditugaskan oleh Badan dan/atau Pejabat Pemerintahan diatasnya; b. merupakan pelaksanaan tugas rutin. 2. Pejabat yang melaksanakan tugas rutin sebagaimana dimaksud pada ayat (1) huruf (b) terdiri atas: a. pelaksanaan harian yang melaksanakan tugas rutin dari pejabat definitif yang berhalangan tetap. 3 . Badan dan/atau Pejabat Pemerintahan dapat memberikan mandat kepada Badan dan/atau Pejabat Pemerintahan lain yang menjadi bawahannya, kecuali ditentukan lain dalam ketentuan peraturan perundang-undangan. 4. Badan dan/atau pejabat pemerintahan yang menerima mandat harus menyebutkan atas nama badan dan/atau pejabat pemerintahan yang memberikan mandat. 5. Badan dan/atau Pejabat yang memberikan mandat dapat menggunakan sendiri wewenang yang telah diberikan melalui mandat, kecuali ditentukan lain dalam ketentuan peraturan perundangundangan. 6. Dalam hal pelaksanaan wewenang berdasarkan mandat menimbulkan ketidak efektifan penyelenggaraan pemerintahan, Badan dan/atau Pejabat Pemerintahan yang memberikan mandat dapat menarik kembali wewenang yang telah dimandatkan. 7. Badan dan/atau Pejabat Pemerintahan yang memperoleh wewenang melalui mandat tidak berwenang mengambil keputusan dan/atau tindakan yang bersifat strategis yang berdampak pada perubahan status hukum pada aspek organisasi, kepegawaian, dan alokasi anggaran. 8. Badan dan/atau Pejabat Pemerintahan yang memperoleh wewenang melalui mandat tanggung jawab kewenangannya tetap pada pemberi mandat.

Dari seluruh rangkaian uraian-uraian atas Pasal 8, 9, 10, dan 12 dari Undang-Undang Nomor 30 Tahun 2014 tentang Administrasi Pemerintahan, yang diuraikan diatas, maka dapat dikatakan bahwa "terwujudnya kewenangan pemerintahan yang berdasarkan peraturan perundang-undangan dan AUPB" merupakan juga kualitas yang diinginkan didalam penyelenggaraan pemerintahan di Indonesia. 
Edisi XIX Volume 1, Januari - Juni 2019

Jurnal Penelitian dan Karya Ilmiah

\section{PENUTUP}

\section{Kesimpulan}

Dari semua uraian yang telah dipaparkan dimuka, atas tulisan yang berjudul FUNGSI UNDANG-UNDANG NOMOR 30 TAHUN 2014 TENTANG ADMINISTRASI PEMERINTAHAN TERHADAP KUALITAS PENYELENGGARAAN PEMERINTAHAN DI INDONESIA, dapat ditarik suatu kesimpulan sebagai berikut:

1. Dari beberapa bahasan tentang Fungsi Pemerintahan, tentang Badan dan/atau Pejabat Pemerintah, tentang Kewenangan Pemerintahan, tentang Keputusan Administrasi Pemerintah, tentang Tindakan Administrasi Pemerintah dan ditambah dengan maksud dan tujuan Undang-Undang Nomor 30 Tahun 2014 tentang Administrasi Pemerintahan, sebagaimana yang telah diuraikan dimuka dapat dikatakan bahwa Undang-Undang Nomor 30 Tahun 2014 tentang Administrasi Pemerintahan ini sangatlah penting dan diperlukan atau dibutuhkan didalam penyelenggaraan pemerintahan di Indnesia, yaitu sebagai acuan untuk meningkatkan kualitas penyelenggaraan pemerintahan di Indonesia.

2. Adapun kualitas yang diinginkan didalam penyelenggaraan pemerintahan di Indonesia adalah antara lain :

a. Agar Badan dan/atau Pejabat Pemerintahan didalam menggunakan kewenangan haruslah mengacu pada Asas-asas Umum Pemerintahan yang Baik (AUPB) dan Ketentuan Peraturan Perundang-undangan,

b. Agar tercapai tujuan administrasi pemerintahan seperti menciptakan tertib penyelenggaraan administrasi pemerintah, menciptakan kepastian hukum, mencegah terjadinya penyalahgunaan wewenang, menjamin akuntabilitas Badan dan/atau Pejabat Pemerintahan, memberikan perlindungan hukum kepada masyarakat dan aparatur pemerintah, melaksanakan ketentuan peraturan perundangundangan, menciptakan Asas-asas Umum Pemerintahan yang Baik (AUPB) dan memberikan pelayanan yang sebaik-baiknya kepada warga negara / masyarakat,

c. Terwujudnya hak dan kewajiban pejabat pemerintah,

d. Terwujudnya kewenangan pemerintah yang berdasarkan peraturan perundang-undangan dan AUPB. 
FUNGSI UNDANG-UNDANG NOMOR 30 TAHUN 2014 TENTANG ADMINISTRASI PEMERINTAHAN TERHADAP KUALITAS PENYELENGGARAAN PEMERINTAHAN DI INDONESIA

\section{Saran}

M. Yusuf Leman

Agar supaya cita-cita atau visi misi Negara Kesatuan Republik Indonesia yang tercantum dalam pembukaan (preambul ) Undang-Undang Dasar yaitu : melindungi segenap bangsa Indonesia dan seluruh tumpah darah Indonesia dan untuk memajukan kesejahteraan umum, mencerdaskan kehidupan bangsa, dan ikut melaksanakan ketertiban dunia yang berdasarkan kemerdekaan, perdamaian abadi, dan keadilan sosial tercapai, disarankan kepada seluruh aparat penyelenggaraan pemerintahan, baik yang berada diwilayah legislatif, yudikatif, dan apalagi di eksekutif hendaknya Undang-Undang Dasar Tahun 1945, dan Undang-Undang Nomor 30 Tahun 2014 tentang Administrasi Pemerintahan benar-benar dijadikan acuan atau pedoman didalam penyelenggaraan pemerintahan. Namun, disamping itu hendaknya juga agar menggunakan prinsip; bahwa apa yang dilakukan didalam penyelenggaraan pemerintahan adalah merupakan perbuatan ibadah, yang kelak akan dipertanggung jawabkan kepada Allah SWT diyaumil akhir nanti. Dan dengan demikian keimanan dan ketakwaan serta bertawakal kepada Allah SWT adalah sebagai hal yang utama untuk dijadikan prinsip didalam bekerja.

\section{REFERENSI}

Al bahij, azmi. 2001. Sejarah 34 Provinsi Indonesia. Jakarta: Dunia Cerdas.

Sinar Grafika. 2014. Undang-Undang Administrasi Pemerintahan dan Kependudukan. Jakarta: Sinar Grafika.

Sumpena. 2011. Penerapan Good Governance dan Pemberantasan Korupsi dilingkungan Pemerintah Pusat dan Daerah, dalam Jurnal Socio Political - Wawasan Akademika Vol. 13 No. 1 Desember 2011. Tangerang: Lembaga Penerbit Prodi Ilmu Administrasi Negara FISIP UNIS Tangerang.

Tim Penyusun Kamus Pusat Pembinaan dan Pengembangan Bahasa. 1988. Kamus Besar Bahasa Indoneisa. Jakarta: Balai Pustaka.

Tim Visi Yustisia. 2015. UUD 1945 Kabinet Kerja Reshtufle - Lembaga-Lembaga Negara beserta Pimpinanya. Jakarta: Visi Media.

Tim Redaksi. 2014. UUD 1945 (amandemen) \& Kabinet Kerja Jokowi - JK 20142019. Sleman Yogyakarta: Cemerlang Publishing. 